\title{
Regenerative medicine for insulin deficiency: creation of pancreatic islets and bioartificial pancreas.
}

$\operatorname{AUTHOR}(\mathrm{S})$ :

Sumi, Shoichiro

\section{CITATION:}

Sumi, Shoichiro. Regenerative medicine for insulin deficiency: creation of pancreatic islets and bioartificial pancreas.. Journal of hepato-biliary-pancreatic sciences 2011, 18(1): 6-12

\section{ISSUE DATE:}

2011-01

URL:

http://hdl.handle.net/2433/141997

\section{RIGHT:}

The final publication is available at www.springerlink.com; This is not the published version. Please cite only the published version.; この論文 は出版社版でありません。引用の際には出版社版をご確認ご利用くだ さい。 


\section{JHPBS2009}

Regenerative medicine for insulin deficiency: creation of pancreatic islets and bioartificial pancreas.

Shochiro Sumi, MD, PhD 1,2)

1: Institute for Frontier Medical Sciences, Kyoto University 2: CREST, JST

Shogoin-Kawara-cho 53, Sakyo-ku, Kyoto, Japan 606-8507

Tel: $+81-75-751-4848$

Fax: +81-75-751-4145

E-mail: sumi@frontier.kyoto-u.ac.jp

\section{Abstract}

Recent advances in pancreas organogenesis greatly improved the understanding of cell lineage from inner cell mass to fully differentiated $\beta$-cells. Upon such knowledge, insulin-producing cells similar to $\beta$-cell to certain extent are generated from various cell sources including embryonic stem cells (ESCs) and induced plurimotent stem (iPS) cells, although fully differentiated cells comparable to $\beta$-cell are not yet available. Bioartificial pancreas is a therapeutic approach to enable allo- and $^{-}$ xeno-transplantation of islets without immune. Among several types of bioartificial pancreas, micro-encapsulated porcine islets are already used in clinical trials and, perhaps, replace islet transplantation in the near future. Some types of bioartificial pancreas such as macro-encapsulation are also useful to keep transplanted cells to be enclosed for possible need of retrieval. Therefore, early clinical applications of artificially generated $\beta$-like cells, especially those from ESCs or iPS cells, will be considered in combination of retrievable BAP.

\section{Introduction}

Diabetes mellitus (DM) is a heterogenous metabolic disease that is eventually attributed to insulin deficiency, which is especially true in type 1 diabetes mellitus (T1DM) in which insulin producing $\beta$-cells residing in islets of Langerhans of the pancreas are primarily destroyed by autoimmune response or other unknown causes. Therefore, patients of T1DM need insulin replacement or endogenous $\beta$-cell reconstruction if exogenous insulin cannot maintain proper blood glucose control. The latter is currently achieved only by either pancreas or islet transplantation. However, these transplantation therapies share common problems of donor scarcity and adverse effects of immune suppression.

The number of people suffering from DM in the world is estimated to be 285 million in 
2010 and to become 439 million in 2030 1. This estimation and many other predictions are warning about the possibility that increasing number of DM patients will cause serious socio-economical burden unless effective and efficient therapies are developed for cure and prevention of DM.

Regenerative medicine is the process of creating living, functional tissues to repair or replace tissue or organ function lost due to age, disease, damage, or congenital defects ${ }^{2}$. In DM, especially in T1DM, what is lost is $\beta$-cell function. Therefore, regenerative medicine for DM is to create endogenous $\beta$-cell function. Toward this end, many possible approaches, ranging from in situ regeneration of islet of Langerhans to mechanical artificial pancreas ${ }^{3}$, are explored. Among these approaches, remarkable advancements in ex vivo creation of cells with $\beta$-cell-like function ( $\beta$-like cells) from various cell sources are recently achieved and, with great expectations, may lead to cellular therapy for T1DM. This article will briefly review these advancements. And then, recent state of bio-artificial pancreas (BAP) will be also reviewed, since BAP that enables cell transplantation without immune suppression should be an essential technology for ideal cellular therapy using ex vivo created $\beta$-like cells.

\section{In vivo differentiation and growth of $\beta$-cell}

Studies in developmental biology, using knockout animals and lineage tracing, have revealed how $\beta$-cell develops in vivo. Several important steps are summarized in Figure 1 , which was modified from a figure in our old review article ${ }^{4}$. In these, pancreatic and duodenal homeobox-1 (Pdx1, also known as IPF1, STF1, and IDX1) is a master gene for the pancreas, since $\mathrm{Pdx} 1$-ko mice lack the pancreas, and also an important transcription factor for insulin ${ }^{5}$. Neurogenin 3 (Ngn3, also known as Math4B and Atoh5) is an essential transcription factor for pancreatic endocrine cells. Ngn3-positive and hormone-negative cells, although such cells were hardly observed in adult animals, were observed within or adjacent to pancreatic ducts in embryonic stages, and considered to be a common progenitor of all islet cells ${ }^{6,7}$. Recently, Ngn3-positive cells were found and isolated in partial duct ligation model of adult mice ${ }^{8}$, suggesting islet neogenesis in adult pancreas as discussed later. In addition to $\operatorname{Pdx} 1$, other factors including MafA and Nkx2.2 play important roles in expression of $\beta$-cell-specific genes as well as insulin. Therefore, these transcription factors are important to maintain $\beta$ cell function 9 .

Islet tissue shows approx. 20-fold growth after birth in rodents and humans, and it also shows additional compensatory growth in response to increased demand, e.g. obesity and pregnancy ${ }^{10}$. In addition, significant pancreatic regeneration occurs after 
major pancreatectomy $(\mathrm{Px})^{11,12}$ and some types of injury in rodents.

Until recently, there was a long discussion about which cells are responsible for the growth and regeneration of islets and, more fundamentally, whether formation of new islets (neogenesis) really occurs or not. However, recent lineage tracing experiments are expected to put an end to this discussion. Dor et al. generated a transgenic mouse strain in which insulin promoter drives the expression of tamoxifen-dependent Cre recombinase and, further, Cre activates a reporter gene. Thus, in this mouse, reporter gene is only expressed in insulin-expressing cells present at the pulse of tamoxifen, as well as their progeny. They have shown that all $\beta$-cells at the observation time point used to be or progeny of $\beta$-cells present at the tamoxifen injection, suggesting that adult pancreatic $\beta$-cells are formed by self-duplication (replication) in normal life-time and even after minor (70\%) Px ${ }^{13}$. On the other hand, as mentioned above, Xu et al. have found Ngn3-positive cells in ductal lining of adult injured pancreas and shown that these cells can become islet cells both in situ and in vitro ${ }^{8}$. In addition, Bonner-Weir and her colleagues performed duct-specific lineage tracing experiments using carbonic anhydrase II (CAII) as a marker to test their hypothesis that mature duct epithelial cells are pancreatic progenitor. Their results show that formation of both new islets and newly differentiated acini from CAII-expressing ductal progenitors occurs during neonatal period 14,15 and that substantial number of islets are genetically marked in duct ligated pancreatic lobe ${ }^{14}$. Acinar cell-specific lineage tracing of similar technique have been reported 16,17. According to these reports, acinar cells contribute to metaplastic duct formation in pancreatitis models but do not become a $\beta$-cell after $\mathrm{Px}$, exendin-4 treatment, duct ligation, or chemical pancreatitis. Taken together, new $\beta$-cells seem to be formed in adult pancreas either through replication of pre-existing $\beta$-cells or islet neogenesis from duct epithelial cells depending on circumstances, but not from acinar calls (Fig 2). Very recently, Solar et al. expressed their negative view for islet neogenesis from the duct in their report dealing with $\mathrm{Hnf} \beta$-positive cells that appear early in pancreatogenesis and gradually restrained during gestation 18 . Therefore, neogenesis issue may need to be discussed a little longer until its settlement.

Various cell sources for $\beta$-like cells

In vitro treatments can induce insulin-producing cells from wide range of cell sources. A number of reports have indicated that insulin-producing cells similar to $\beta$-cell to certain extent can be induced in various type of adult cells derived from bone marrow ${ }^{19}$, umbilical cord blood 20, liver ${ }^{21}$, intestine ${ }^{22}$, and so on ${ }^{4}, 23$, after introduction of 
pancreatic lineage-related genes such as $\operatorname{Pdx} 1$. Protein transduction is another method to change cell fate as well as cell function. Protein transduction of $\operatorname{Pdx} 1$, BETA2/NeuroD and other factors are shown to enhance differentiation to $\beta$-cell 24 . In addition to adult stem cells, Wei et al 25 showed that human amniotic epithelial cells can produce insulin mRNA under nicotinamide stimulation in vitro and can produce human insulin in several weeks when implanted in streptozotocin-diabetic mice. These studies indicate that various cell types can be used for generate $\beta$-like cells, although these generated cells are not so mature as $\beta$-cell in most cases and there remains safety concern if they are gene-engineered.

Pancreas-derived cells are other cell sources since exocrine pancreatic tissue is a waist after islet isolation for transplantation. Ramiya et al. ${ }^{26}$ have reported that pancreatic duct epithelial cells obtained from adult non-obese diabetic (NOD) mice can continuously produce islet-like cell clusters after long term culture and that hyperglycemia can be controlled by transplantation of these clusters. Following this, similar in vitro generation of $\beta$-like cells from cultured duct-like cells has been reported from several other groups (please refer to the other reviews 27,28 . In addition, this differentiation is shown to be mediated, at least partly, through phosphatidylinositol-3 kinase-related pathway ${ }^{29}$.

As mentioned earlier, acinar cells are shown not to contribute to endocrine cell growth in vivo, but they are shown to generate $\beta$-like cells in vitro through formation of cell cluster in suspension culture ${ }^{30}$. Furthermore, recent report showed that exocrine cells can be directly converted to $\beta$-cells in vivo by introducing three transcription factors, Pdx1, Ngn3 and MafA 31. In addition to duct and acinar cells, cells showing less differentiated fibroblast-like appearance can be cultured from pancreatic tissue. Baertschiger et al. showed that these highly proliferative cells express transcription factors implicated to $\beta$-cell development as well as several mesenchymal stem cell (MSC)-specific markers, yet it is not clear whether these cells can re-differentiate to $\beta$-like cells ${ }^{32}$. Taken together, pancreatic duct-like cells, and even acinar cells, seem potential source for $\beta$-like cells, although the details of these phenomena are mostly unknown and, in general, the growth of these cells is slow. In this aspect, MSC-like cells from the pancreas, with high proliferative ability, may be another candidate.

Embryonic stem cell (ESC) is an attractive cell source for any kind of cell therapies, because they proliferate almost indefinitely and has very wide differentiation potency (pluripotency). Since the establishment of ESC 33,34, many groups have studied $\beta$-cell 
differentiation form ESC. In earlier attempts of Lumelsky et al. ${ }^{35}$ and many other groups including ours ${ }^{36}$, insulin-producing cell clusters were generated through nestin-positive cells by step-wise procedures somewhat similar to ones for neural cell differentiation. However, these cells can hardly be regarded as $\beta$-like cells after the report by Rajagopal et al. ${ }^{37}$, in which insulin-positive cells were shown to result mostly by insulin up-take from the culture medium. It is known that several types of insulin-producing cells other than $\beta$-cell appear in certain neuronal cell, yolk sac and liver during embryonic development ${ }^{38}$. Therefore, insulin staining and mRNA expression in these early studies are now considered to be attributed mostly to differentiation toward neuron-like cells or extra-embryonic endoderm ${ }^{39}$, although our study showed insulin granules by electron microscope, mRNA expression of pancreatic genes such as glucagon and amylase as well as insulin and, further, significant decrease in blood glucose after transplantation to diabetic mice ${ }^{36}$. Anyway, lessons from these earlier attempts emphasize the importance of understanding developmental biology about pancreas and $\beta$-cell.

Assady et al. reported generation of insulin-secreting cells from ESC after spontaneous differentiation, although the number of such cells and insulin content in them was low ${ }^{40}$. However, their study clearly showed the possibility that $\beta$-like cells can be generated from ESC, and subsequent studies employed strategies that closely follow the differentiation steps toward $\beta$-cell during embryogenesis, namely ESC definitive endoderm, primitive gut tube, posterior foregut, pancreatic endoderm, endocrine presursor and finally islet of Langerhans. Following these multiple steps, D'Amour et al. generated cells that release C-peptide in response to multiple secretory stimuli from human ESCs, but they were only minimally responsive to glucose ${ }^{41}$. Therefore, their methods still need some steps that induce final differentiation of $\beta$-cells, e.g. second wave expression of $\operatorname{Pdx} 1$ and MafA expression. In the sasme line of study, Kroon et al. recently reported that pancreatic endoderm derived from human embryonic stem (hES) cells efficiently generates glucose-responsive endocrine cells after implantation into mice ${ }^{42}$. In this study, pancreatic endoderm-like tissue that contains few hormone-expressing cells was generated in vitro and then transplanted into epididymal fat pad to allow further development in vivo. Then, the graft became fully responsive to glucose 3 months after transplantation. So far, the factors that induce final $\beta$-cell differentiation are unknown, but may be simply time longer than allowed for the in vitro protocols, or difficult to reproduce in vitro, such as vascularization and the interaction with adjacent tissues ${ }^{43}$. Several other groups also reported in vitro differentiation of $\beta$-like cells from human ESCs, through definitive 
endoderm with distinct methods 44,45 .

Induced pluripotent stem (iPS) cell 46 is an artificial cell type that is generated from somatic cells to mimic ESC. Human iPS cells avoid the ethical difficulties regarding the use of human embryos and tissue rejection following transplantation if they are generated from patients' own cells. The protocols used in humsn ESCs, iPS cells are also shown to differentiate into $\beta$-like cells in vitro ${ }^{47,48}$. ESC and iPS cells are potential and indefinite cell source for cell therapies. However, further studies are needed toward the final differentiation of $\beta$-like cells as well as to establish acceptable safety until clinical usage.

\section{Bioartificial pancreas}

The original concept of BAP is to enable islet transplantation without immune suppression by protecting islets with semipermeable barrier against immune rejection (Fig 3). BAP can be used not only allotransplantation but also xenotransplantation of the islets depending on the immuno-isolation property of the barrier.

As described above, artificial generation of $\beta$-like cells are intensely investigated. If any of these studies reach the end to supply sufficient amount of $\beta$-like cells of sufficient quality, transplantation of these cells, as well as human islets, will be regarded as a possible treatment for T1DM. However, one major difficulty in this approach is that the transplanted cells are exposed to the patient's inflammatory and autoimmune environment, which originally destroyed their own $\beta$-cells. Therefore, even if a good source of $\beta$-like cells can be identified for transplantation therapy, these cells need to be protected against these destructive influences. Therefore, BAP is expected to play an important role in future cellular therapy for T1DM.

BAP can be classified into several types, namely diffusion chamber, blood perfusion and encapsulation types (Fig. 4). Each type has its advantages and drawbacks as described below.

In diffusion chamber type, islets are contained in the space surrounded by semipermeable membrane. Typically, islets are contained between two semipermeable membranes placed on both side of ring-like structure ${ }^{49}$. In addition, islets placed in hollow fibers can be regarded as a particular type of this kind. The structure of this type is rather simple and you can choose optimal membrane with desired pore size. On the other hand, islets tend to clump each other and undergo central necrosis. To place islets with some types of hydrogel such as agarose can avoid this clumping and improve BAP function ${ }^{50}$. Our group has developed mesh-reinforced polyvinyl alcohol (PVA) tube and bag of this type ${ }^{51}$. Recently, Yang et al. developed a chamber implantable to bone 
marrow cavity using calcium phosphate cement as immunoisolative device to enclose insulinoma/agarose microspheres 52 and reported therapeutic used of this to spontaneously diabetic cat ${ }^{53}$.

Blood perfusion type is similar to dialysis device. Blood is perfused in the hollow fiber and islets are placed around the fibers. The advantage of this type is high diffusive exchange rate, however this type is hardly implantable in a body and needs some anticoagulation treatment. Ikeda et al. developed BAP of this type and showed its effect in pancreatectomized pigs ${ }^{54}$.

Encapsulation type can be divided in to two categories, namely micro-encapsulation and macro-encapsulation. In micro-encapsulation, one or a few islets are encapsulated in hydrogel, such as alginate, like micro-beads. This type is favorable for substance exchange because of its large surface area. However, this type is hardly retrievable once they are implanted into the body, for example abdominal cavity. Most famous example of this type is DIABECELL®, a product of a bio-venture company, Living Cell Technologies 55,56 . It is a porcine insulin-producing cell micro-encapsulated in alginate hydrogel. Micro-beads are implanted into the abdominal cavity of the patients without any immune suppretion. According to their announcement on the internet, Phase I and II clinical trials are now ongoing in Russia and New Zealand. And, so far, beneficial effects, such as reduced HbA1c levels and/or reduced insulin doses including insulin independence are observed without serious adverse effects. Therefore, their clinical trials are showing promising capability of micro-encapulated islets. However, micro-beads implanted in the abdominal cavity are not retrievable. So, this method will not be suitable for the early application of artificially generated $\beta$-like cells unless safety of such cells become proven at high levels.

In contrast to micro-encapsulation, macro-encapsulation encloses islets in a lager hydrogel that can be handled macroscopically. Therefore, macro-encapsulated islets are easy to retrieve and seemingly suitable for early use of artificially generated $\beta$-like cells, because it can be retrieved if any kind of adverse events such as tumor formation. Our group developed macro-encapsulated islets using agarose-based hydrogel and showed the effect in xenotransplantation into prevascularized subcutaneous site 57, 58. Another example of this type of BAP is PVA-macro-encapsulated islets. We developed this device through combination of cryo-preservation methods of islets and hydrogel formation from PVA aqueous solution by freezing and thawing ${ }^{59}$. Implantation of this BAP was show to prevent renal dysfunction observed in severely diabetic mice, suggesting reconstruction of basal insulin secretion by BAP is really effective to prevent diabetic complications, at least to certain extent 60 . 
Conclusions and prospective

Recent advances in the study of pancreatic organogenesis revealed cell lineage of $\beta$-cells and important steps from inner cell mass from which ESCs are established to fully differentiated $\beta$-cells. Understanding these informations is important to establish efficient protocol of $\beta$-cell differentiation from other cell types, especially from ESCs and iPS cells. $\beta$-like cells can be generated from various cell sources with/without gene transfer. However, fully differentiated $\beta$-like cells with high insulin production and glucose responsibility comparable to $\beta$-cells are not yet available. Further studies on $\beta$-cell differentiation are expected to solve this problem. Among various cell sources, pancreas-derived somatic cells might be most promising since even highly proliferative MSC-like cells isolated from pancreas express several pancreas-specific genes suggesting that they stay at certain stage on the way to $\beta$-cell differentiation.

BAP that enables islet allo- and xeno-transplantation without immune suppression is a promising therapeutic approach for T1DM. Micro-encapsulated porcine islets are already used in clinical trials and, perhaps replace islet transplantation in the near future. Some types of BAP such as macro-encapsulation are also useful to keep transplanted cells to be enclosed for possible need of retrieval. Therefore, early clinical applications of artificially generated $\beta$-like cells, especially those from ESCs or iPS cells, will be considered in combination of retrievable BAP.

\section{Reference}

1. International Diabetes Federation web site, IDF Diabetes Atlas: http://www.diabetesatlas.org/content/diabetes-and-impaired-glucose-tolerance

2. National Institute of Health web site, Fact Sheet, Regenerative Medicine: http://www.nih.gov/about/researchresultsforthepublic/Regen.pdf

3. Hoshino M, Haraguchi Y, Mizushima I, Sakai M. Recent progress in mechanical artificial pancreas. J Artif Organs. 2009; 12: 141-149.

4. Sumi S, MD PhD, Gu YJ, Hiura A, MD PhD, Inoue K. Stem Cells and Regenerative Medicine for Diabetes Mellitus. Pancreas 29: e85-e89, 2004

5. Jonsson J, Ahlgren U, Edlund T, Edlund H. IPF1, a homeodomain protein with a dual function in pancreas development. Int J Dev Biol. 1995; 39: 789-798.

6. Gradwohl G, Dierich A, LeMeur M, Guillemot F. Neurogenin3 is required for the development of the four endocrine cell lineages of the pancreas. Proc Natl Acad Sci USA. 2000; 97: 1607-1611.

7. Schwitzgebel VM, Scheel DW, Conners JR, Kalamaras J, Lee JE, Anderson DJ, et 
al. Expression of neurogenin3 reveals an islet cell precursor population in the pancreas. Development. 2000; 27: 2533-2542.

8. Xu X, D'Hoker J, Stangé G, Bonné S, De Leu N, Xiao X, et al. Beta cells can be generated from endogenous progenitors in injured adult mouse pancreas. Cell. 2008; 132: 197-207.

9. Bernaldo AS, Hay CW, Docherty K. Pancreatic transcription factors and their role in the birth, life and survival of the pancreatic $\beta$ cell. Mol Cell Endocrinol 2008; 294: 1-9.

10. Bonner-Weir S, Perspective: postnatal pancreatic $\beta$-cell growth. Endocrinology 2000; 141: 1926-1929.

11. Brockenbrough JS, Weir GC, Bonner-Weir S. Discordance of exocrine and endocrine growth after 90\% pancreatectomy in rats. Diabetes 1988; 37: 232-236.

12. Xu G, Sumi S, Koike M, Tanigawa K, Nio Y, Tamura. K. Role of endogenous hypergastrinemia in regenerating endocrine pancreas after partial pancreatectomy. Dig Dis Sci 1996; 41: 2433-2439.

13. Dor Y, Brown J, Martinez OI, Melton DA. Adult pancreatic beta-cells are formed by self-duplication rather than stem-cell differentiation. Nature. 2004; 429: 41-6.

14. Bonner-Weir S, Inada A, Yatoh S, Li WC, Aye T, Toschi E, et al. Transdifferentiation of pancreatic ductal cells to endocrine beta-cells. Biochem Soc Trans. 2008; 36: 353-356.

15. Inada A, Nienaber C, Katsuta H, Fujitani Y, Levine J, Morita R, et al. Carbonic anhydrase II-positive pancreatic cells are progenitors for both endocrine and exocrine pancreas after birth. Proc Natl Acad Sci U S A. 2008; 105: 19915-19919.

16. Strobel O, Dor Y, Alsina J, Stirman A, Lauwers G, Trainor A, et al. In vivo lineage tracing defines the role of acinar-to-ductal transdifferentiation in inflammatory ductal metaplasia. Gastroenterology. 2007; 133: 1999-2009.

17. Desai BM, Oliver-Krasinski J, De Leon DD, Farzad C, Hong N, Leach SD, et al. Preexisting pancreatic acinar cells contribute to acinar cell, but not islet beta cell, regeneration. J Clin Invest. 2007; 117: 971-7.

18. Solar M, Cardalda C, Houbracken I, Martín M, Maestro MA, De Medts N, et al. Pancreatic exocrine duct cells give rise to insulin-producing beta cells during embryogenesis but not after birth. Dev Cell. 2009; 17: 849-860.

19. Moriscot C, de Fraipont F, Richard MJ, Marchand M, Savatier P, Bosco D, et al. Human bone marrow mesenchymal stem cells can express insulin and key transcription factors of the endocrine pancreas developmental pathway upon genetic and/or microenvironmental manipulation in vitro. Stem Cells. 2005; 23: 
594-603.

20. Parekh VS, Joglekar MV, Hardikar AA. Differentiation of human umbilical cord blood-derived mononuclear cells to endocrine pancreatic lineage. Differentiation. 2009; 78: 232-240.

21. Kojima H, Fujimiya M, Matsumura K, Younan P, Imaeda H, Maeda M, et al. NeuroD-betacellulin gene therapy induces islet neogenesis in the liver and reverses diabetes in mice. Nat Med. 2003; 9: 596-603.

22. Kojima H, Nakamura T, Fujita Y, Kishi A, Fujimiya M, Yamada S, et al. Combined expression of pancreatic duodenal homeobox 1 and islet factor 1 induces immature enterocytes to produce insulin. Diabetes. 2002; 51: 1398-1408.

23. Furth ME, Atala A. Stem cell sources to treat diabetes. J Cell Biochem 2009; 106: 507-511.

24. Noguchi H, Matsumoto S. Protein transduction technology offers a novel therapeutic approach for diabetes. J Hepatobiliary Pancreat Surg. 2006; 13: 306-313.

25. Wei JP, Zhang TS, Kawa S, Aizawa T, Ota M, Akaike T, et al. Human amnion-isolated cells normalize blood glucose in streptozotocin-induced diabetic mice. Cell Transplant. 2003; 12: 545-552.

26. Ramiya VK, Maraist M, Arfors KE, Schatz DA, Peck AB, Cornelius JG. Reversal of insulin-dependent diabetes using islets generated in vitro from pancreatic stem cells. Nat Med. 2000; 6: 278-282.

27. Guo T, Hebrok M. Stem cells to pancreatic beta-cells: new sources for diabetes cell therapy. Endocr Rev. 2009; 30: 214-227.

28. Baeyens L, Bouwens L. Can beta-cells be derived from exocrine pancreas? Diabetes Obes Metab. 2008; 10 Suppl 4: 170-178.

29. Watanabe H, Saito H, Ueda J, Evers BM. Regulation of pancreatic duct cell differentiation by phosphatidylinositol-3 kinase. Biochem Biophys Res Commun. 2008; 370: 33-37.

30. Minami K, Okuno M, Miyawaki K, Okumachi A, Ishizaki K, Oyama K et al. Lineage tracing and characterization of insulin-secreting cells generated from adult pancreatic acinar cells. Proc Natl Acad Sci U S A. 2005; 102: 15116-15121.

31. Zhou Q, Brown J, Kanarek A, Rajagopal J, Melton DA. In vivo reprogramming of adult pancreatic exocrine cells to beta-cells. Nature. 2008; 455: 627-632.

32. Baertschiger RM, Bosco D, Morel P, Serre-Beinier V, Berney T, Buhler LH, et al. Mesenchymal stem cells derived from human exocrine pancreas express transcription factors implicated in beta-cell development. Pancreas. 2008; 37: 
75-84.

33. Evans MJ, Kaufman MH. Establishment in culture of pluripotential cells from mouse embryos. Nature. 1981; 292: 154-156.

34. Martin GR. Isolation of a pluripotent cell line from early mouse embryos cultured in medium conditioned by teratocarcinoma stem cells. Proc Natl Acad Sci U S A. 1981; 78: 7634-7638.

35. Lumelsky N, Blondel O, Laeng P, Velasco I, Ravin R, McKay R. Differentiation of embryonic stem cells to insulin-secreting structures similar to pancreatic islets. Science. 2001; 292: 1389-1394.

36. Kim D, Gu Y, Ishii M, Fujimiya M, Qi M, Nakamura N, et al. In vivo functioning and transplantable mature pancreatic islet-like cell clusters differentiated from embryonic stem cell. Pancreas. 2003; 27: e34-41.

37. Rajagopal J, Anderson WJ, Kume S, Martinez OI, Melton DA. Insulin staining of ES cell progeny from insulin uptake. Science. 2003; 299: 363.

38. Devaskar SU, Giddings SJ, Rajakumar PA, Carnaghi LR, Menon RK, Zahm DS. Insulin gene expression and insulin synthesis in mammalian neuronal cells. J Biol Chem. 1994; 269: 8445-54.

39. Milne HM, Burns CJ, Kitsou-Mylona I, Luther MJ, Minger SL, Persaud SJ et al. Generation of insulin-expressing cells from mouse embryonic stem cells. Biochem Biophys Res Commun. 2005; 328: 399-403.

40. Assady S, Maor G, Amit M, Itskovitz-Eldor J, Skorecki KL, Tzukerman M. Insulin production by human embryonic stem cells. Diabetes. 2001;50:1691-1697.

41. D'Amour KA, Bang AG, Eliazer S, Kelly OG, Agulnick AD, Smart NG, et al. Production of pancreatic hormone-expressing endocrine cells from human embryonic stem cells. Nat Biotechnol. 2006; 24: 1392-1401.

42. Kroon E, Martinson LA, Kadoya K, Bang AG, Kelly OG, Eliazer S, et al. Pancreatic endoderm derived from human embryonic stem cells generates glucose-responsive insulin-secreting cells in vivo. Nat Biotechnol. 2008; 26: 443-452.

43. Van Hoof D, D'Amour KA, German MS. Derivation of insulin-producing cells from human embryonic stem cells. Stem Cell Res. 2009; 3: 73-87.

44. Jiang J, Au M, Lu K, Eshpeter A, Korbutt G, Fisk G, et al. Generation of insulin-producing islet-like clusters from human embryonic stem cells. Stem Cells. 2007; 25: 1940-1953.

45. Shim JH, Kim SE, Woo DH, Kim SK, Oh CH, McKay R, et al. Directed differentiation of human embryonic stem cells towards a pancreatic cell fate. 
Diabetologia. 2007; 50:1228-1238.

46. Takahashi K, Yamanaka S. Induction of pluripotent stem cells from mouse embryonic and adult fibroblast cultures by defined factors. Cell. 2006; 126: 663-676.

47. Tateishi K, He J, Taranova O, Liang G, D'Alessio AC, Zhang Y. Generation of insulin-secreting islet-like clusters from human skin fibroblasts. J Biol Chem. 2008; 283: 31601-31607.

48. Zhang D, Jiang W, Liu M, Sui X, Yin X, Chen S, et al. Highly efficient differentiation of human ES cells and iPS cells into mature pancreatic insulin-producing cells. Cell Res. 2009; 19: 429-438.

49. Ohgawara H. Strategies for immunoisolation in islet transplantation: challenges for the twenty-first century. J Hepatobiliary Pancreat Surg. 2000; 7: 374-379.

50. Aung T, Inoue K, Kogire M, Doi R, Kaji H, Tun T, et al. Comparison of various gels for immobilization of islets in bioartificial pancreas using a mesh-reinforced polyvinyl alcohol hydrogel tube. Transplant Proc. 1995; 27: 619-621.

51. Gu YJ, Inoue K, Shinohara S, Doi R, Kogire M, Aung T, et al. Xenotransplantation of bioartificial pancreas using a mesh-reinforced polyvinyl alcohol bag. Cell Transplant. 1994; 3 Suppl 1: S19-S21.

52. Yang KC, Yang YC, Wu CC, Kuo TF, Lin FH. In vitro study of using calcium phosphate cement as immunoisolative device to enclose insulinoma/agarose microspheres as bioartificial pancreas. Biotechnol Bioeng. 2007; 98: 1288-1295.

53. Yang KC, Wu CC, Lin SC, Sumi S, Lin FH. The in vivo performance of bioartificial pancreas in bone marrow cavity: A case report of a spontaneous diabetic feline. Biochem Biophys Res Commun (in press).

54. Ikeda H, Kobayashi N, Tanaka Y, Nakaji S, Yong C, Okitsu T, et al. A newly developed bioartificial pancreas successfully controls blood glucose in totally pancreatectomized diabetic pigs. Tissue Eng. 2006; 12: 1799-1809.

55. Living Cell Technologies web site,

DIABECELL: http://www.lctglobal.com/lct-diabecell-diabetes-treatment.php

56. Elliott RB, Escobar L, Tan PL, Muzina M, Zwain S, Buchanan C. Live encapsulated porcine islets from a type 1 diabetic patient $9.5 \mathrm{yr}$ after xenotransplantation. Xenotransplantation. 2007; 14: 157-161.

57. Wang W, Gu Y, Tabata Y, Miyamoto M, Hori H, Nagata N, et al. Reversal of diabetes in mice by xenotransplantation of a bioartificial pancreas in a prevascularized subcutaneous site. Transplantation. 2002; 73: 122-129.

58. Wang W, Gu Y, Hori H, Sakurai T, Hiura A, Sumi S, et al. Subcutaneous 
transplantation of macroencapsulated porcine pancreatic endocrine cells normalizes hyperglycemia in diabetic mice. Transplantation. 2003; 76: 290-296.

59. Qi M, Gu Y, Sakata N, Kim D, Shirouzu Y, Yamamoto C, et al. PVA hydrogel sheet macroencapsulation for the bioartificial pancreas. Biomaterials. 2004; 25: 5885-5892.

60. Sakata N, Gu Y, Qi M, Yamamoto C, Hiura A, Sumi S, et al. Effect of rat-to-mouse bioartificial pancreas xenotransplantation on diabetic renal damage and survival. Pancreas. 2006; 32: 249-257.

Figure legends

Fig. 1

Schematic over view of pancreas development and important transcription factors involved in this process during embryogenesis (modified from our previous review ${ }^{4)}$ ).

Fig. 2

Schematic relationship and transdifferentiation between pancreatic cell types during regeneration process or in duct-ligated lobes.

Fig. 3

Schematic figure of bioartificial pancreas.

Fig. 4

Schematic figure of several types of bioartificial pancreas. 


\section{foregut}

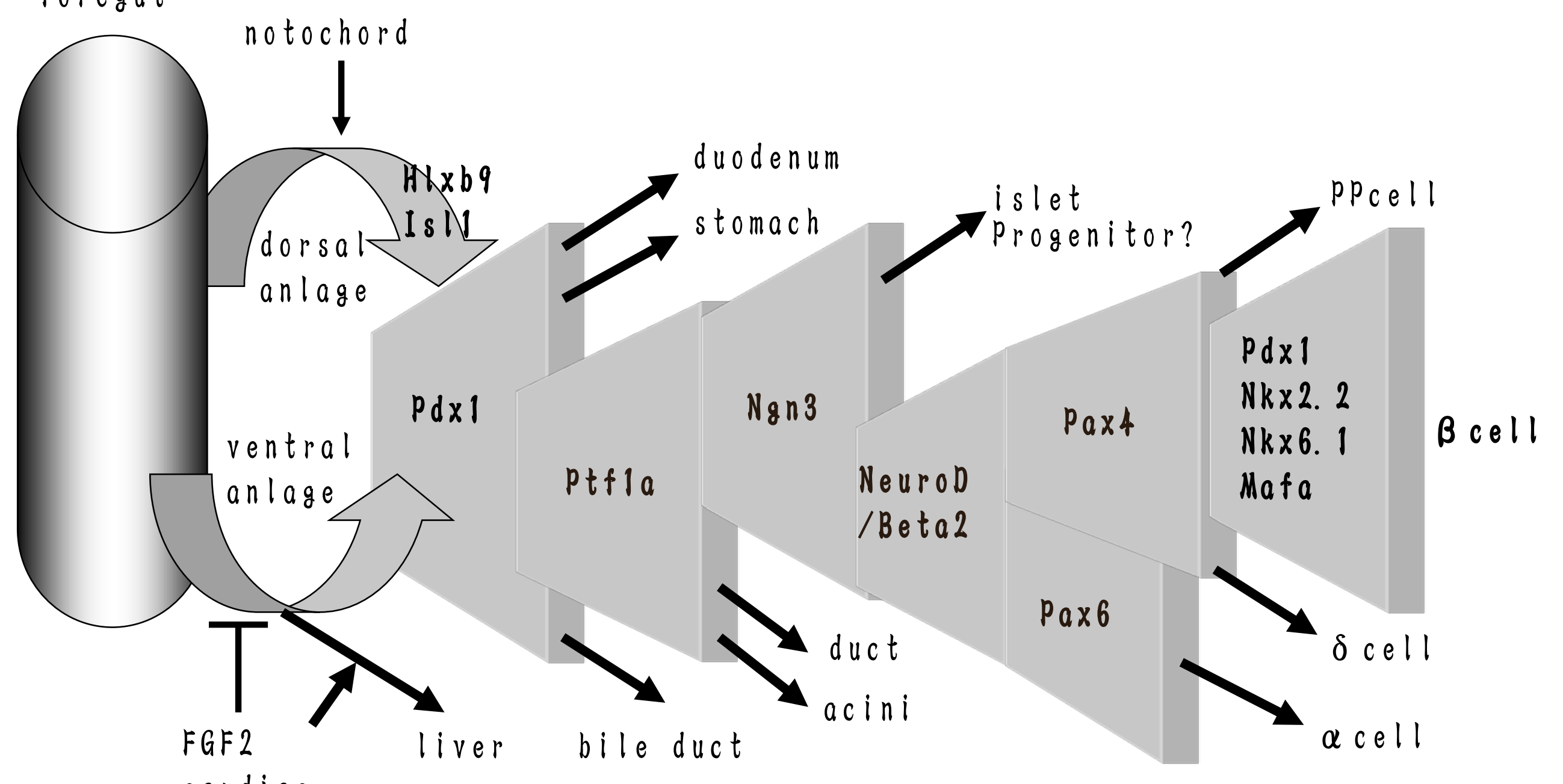

cardiac mesoderm

Fig. 1 


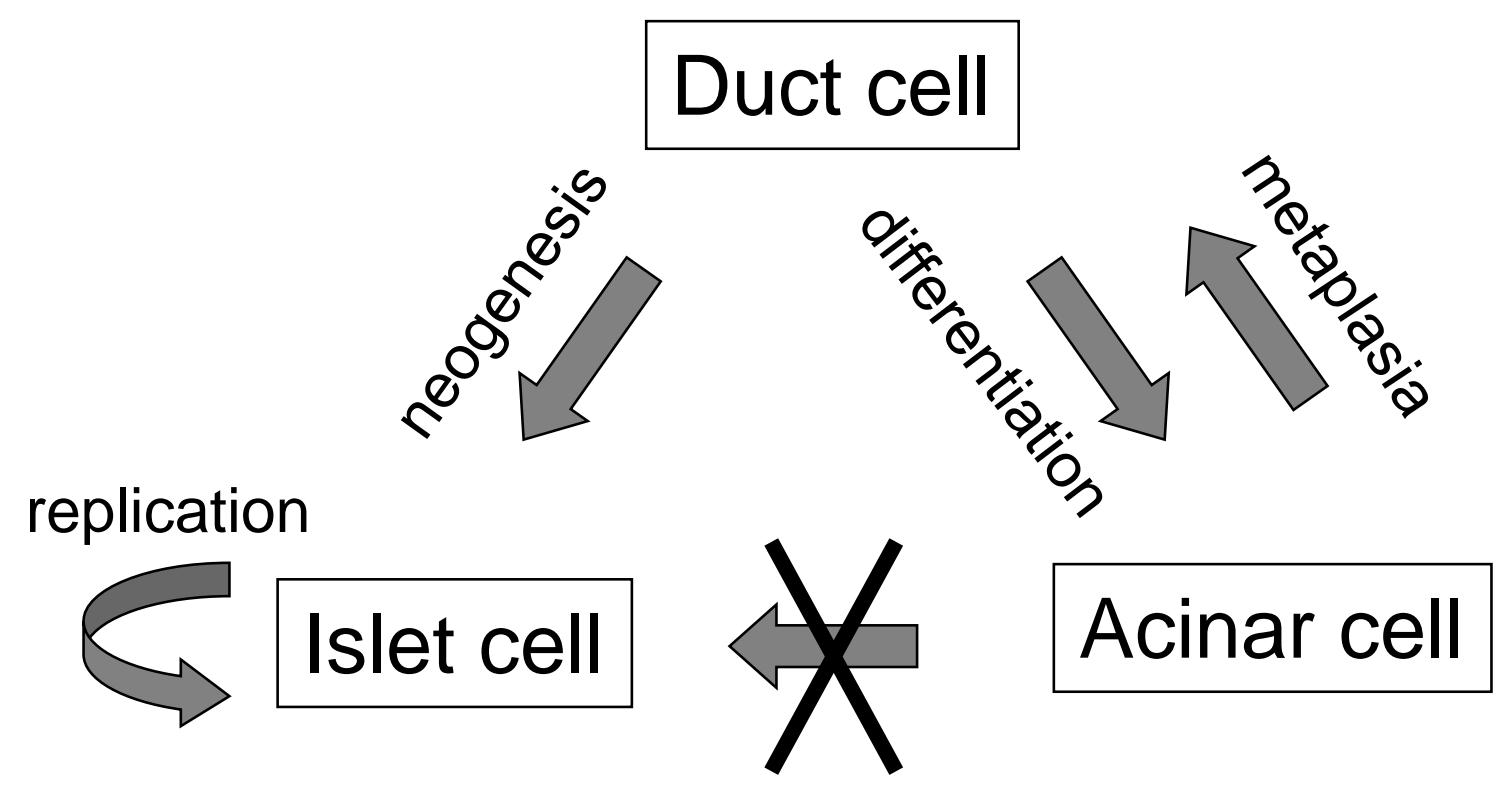

Fig. 2 


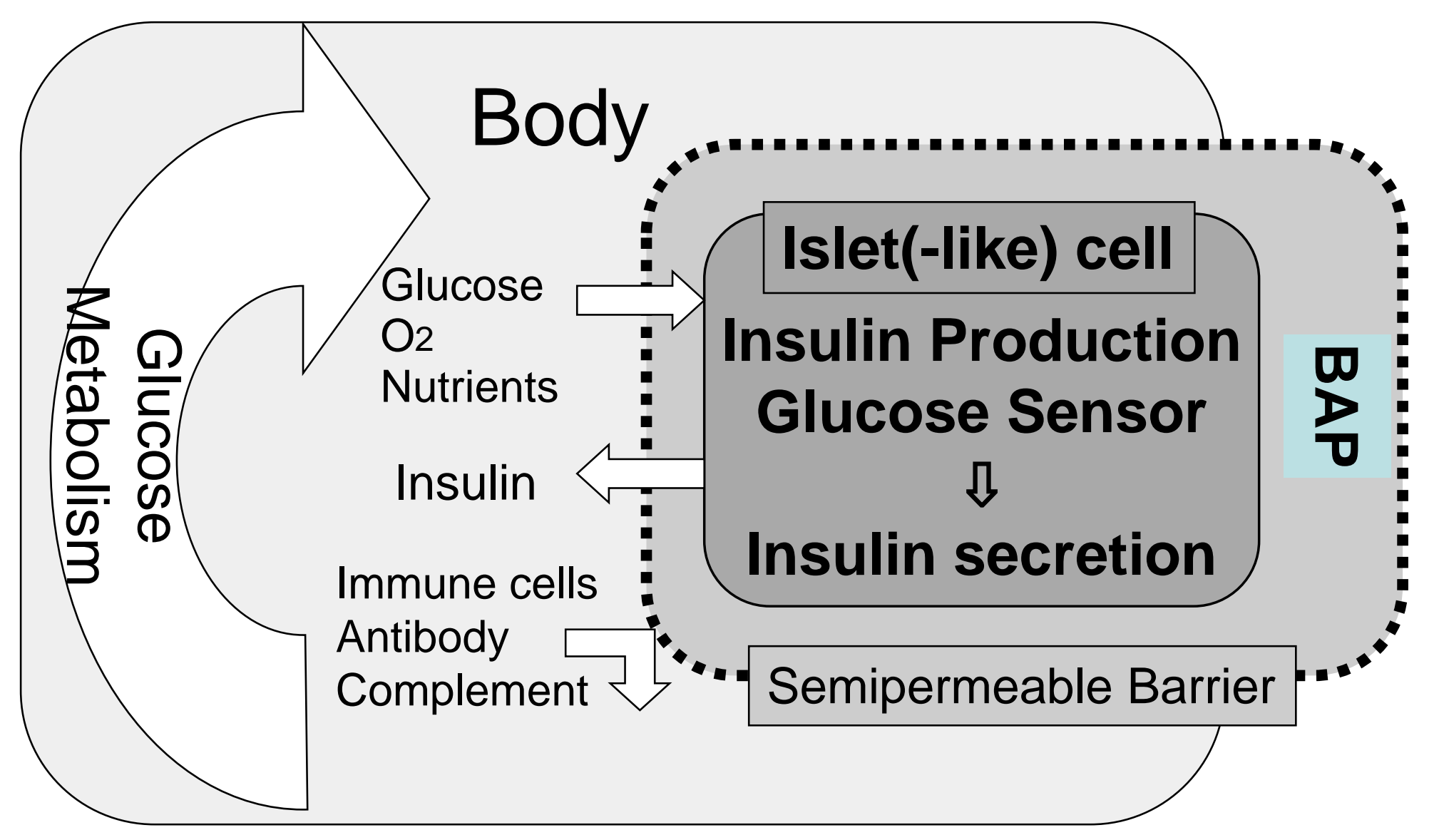

Fig. 3 
Diffusion Chamber Type

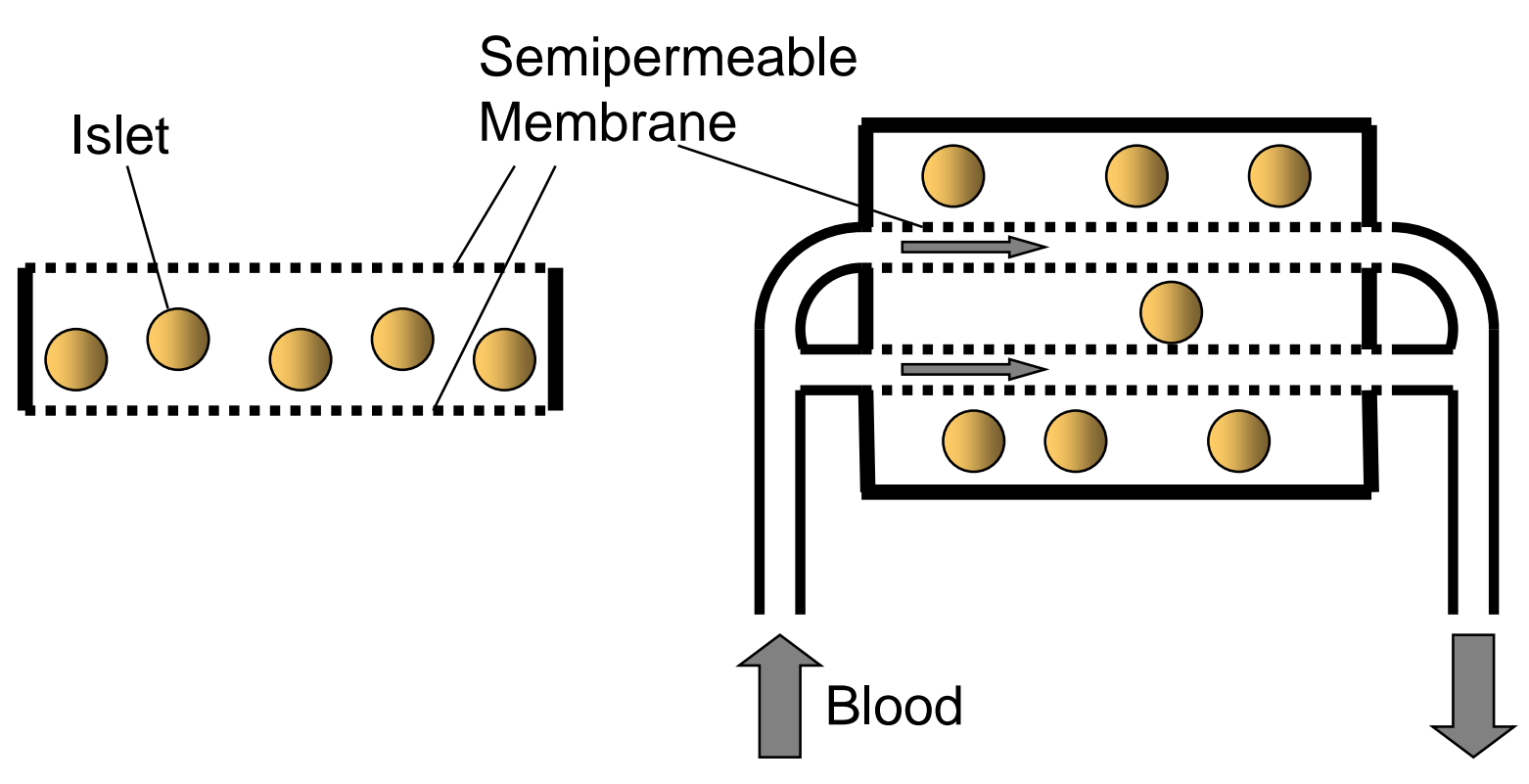

Encapsulation Type

Micro-encapsulation

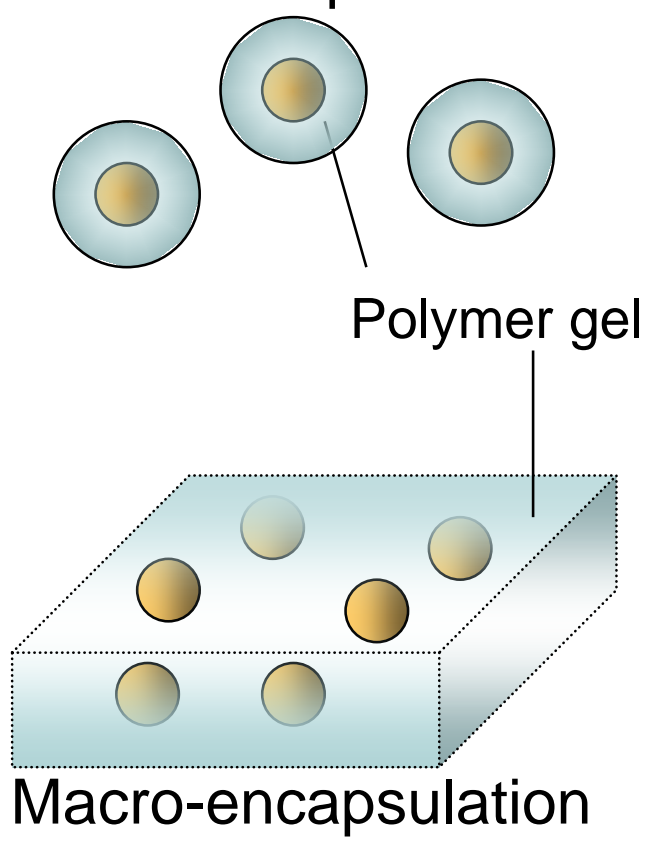

Fig. 4 